\title{
p53 and Bax: Putative Death Factors in Taste Cell Turnover
}

\author{
QUN ZENG AND BRUCE OAKLEY* \\ Department of Biology, U niversity of Michigan, Ann Arbor, Michigan 48109-1048
}

\begin{abstract}
The turnover of cells in renewing epithelia presents an opportunity to examine cell death pathways in adult vertebrates. In mouse lingual epithelium a typical taste receptor cell survives for 9 days, until it is killed by an unknown cascade of death factors. Apoptosis was implicated by the presence of fragmented DNA in about $8 \%$ of tastereceptor cells in the vallate papilla. In using immunocytochemistry to seek putative death factors, we observed that squamous epithelial cells of the tongue were negative for $\mathrm{Bax}$, a death factor in the $\mathrm{Bcl}-2$ family of survival/death factors, and were also negative for p53, a tumor-suppressor protein linked to apoptosis and Bax transcription. In contrast, 8-10\% of the taste receptor cells were Bax-positive, and 9- $11 \%$ were p53 positive. These immunopositive taste receptor cells were more likely to display death-related morphologic defects than other receptor cells, and they frequently coexpressed p53 and Bax. In both neonatal and adult mice, the labeling of dividing cells with 5-bromo-2'-deoxyuridine indicated that all Bax-positive taste cells were at least 5 days old. On postnatal day 7, when few taste cells were old, no more than $1 \%$ of taste cells were immunopositive for either p53 or Bax. We inferred that old tastereceptor cells employ p53 and Bax as part of their apoptotic death pathway. The routine expression of p53 by postmitotic, aged taste cells broadens the conventional view that p53 is restricted to mitotic cells that have stress-damaged DNA. Furthermore, the scattered distribution of aged receptor cells within the taste bud excludes some explanations for stabl e taste signals during receptor cell turnover. J. Comp. Neurol. 413:168-180, 1999. @ 1999 Wiley-Liss, Inc.
\end{abstract}

Indexing terms: apoptosis; epithelium; programmed cell death; sensory coding; skin; squamous cells

In maintaining its structure, a renewing epithelium replaces its aged cells. Consequently, renewing epithelia provide opportunities to examine the regulation of programmed cell death in adult tissues. Programmed cell death also occurs during embryonic development, when a scarcity of essential hormones or other trophic factors can kill a developing cell (Deckwerth et al., 1996; Bergeron and Yuan, 1998). It is not yet known what triggers the programmed death of aged cells during the steady-state homeostasis of adult renewing epithelia (E Ilis et al., 1991; McCall and Cohen, 1991; Haake and Polakowska, 1993; Polakowska et al., 1994; Tamada et al., 1994). Because taste buds are small packets of cells that are identified readily by their specific keratins (Knapp et al., 1995), they are especially suitable for quantitative in situ analysis of renewing epithelial cells. In the present instance, the analysis is directed toward homeostatic cell death pathways.

In considering the origins of homeostatic cell death cascades, it is of interest to examine factors frequently employed by perhaps more primitive stress-induced death cascades. Stressed cells often up-regulate p53, which has become the most intensively studied tumor-suppressor gene because it is the most frequently mutated gene in cancerous tissues (Hollstein et al., 1991; Hansen and Oren, 1997; Levine, 1997; Wiman, 1997). After DNA damage by intense ultraviolet (UV) radiation or other stressors, p53 is expressed and cell division is stalled, thereby gaining time for DNA repair (Kastan et al., 1991; Kuerbitz et al., 1992; Yin et al., 1992). The transcriptional activation by $\mathrm{p} 53$ of the cyclin inhibitor p21 cipl/waf1 is crucial in halting cell division (El-Deiry et al., 1993; Harper et al., 1993). If the ensuing DNA repair is successful, then cell division may restart. However, if DNA repair fails, then the cell can be shunted into a death pathway that may use p53 transcription of bax, a prodeath member of the bcl-2 family of survival/death factors (Sakamuro et al., 1995; Levine, 1997; Yin et al., 1997). Because of its prominence in stress-induced cell death, we sought p53

Grant sponsor: National Science Foundation; Grant number: DIR9014275; Grant sponsor: National Institutes of Health; Grant number: DC-00083.

*Correspondence to: Bruce Oakley, Department of Biology, 3127 Natural Science Building, University of Michigan, Ann Arbor, MI 48109-1048. E-mail: boakley@umich.edu

Received 6J uly 1998; Revised 9 J une 1999; Accepted 18 J une 1999 
expression in taste cells. A low incidence of p53 expression had been reported previously for olfactory receptor cells that also turn over (Huang et al., 1995). If p53 were expressed during the normal life history of postmitotic taste cells, then it would not only prompt a search for coexpression of Bax but also would imply that p53 had a role considerably wider than its canonical association with genomic damage.

Expressed in diverse tissues, the several survival genes within the bcl-2 gene family include bcl-2 and bcl- $x_{L}$. The death-promoting genes of the bcl-2 family include bax (Oltvai et al., 1993), bak (Chittenden et al., 1995; Farrow et al., 1995; Kiefer et al., 1995), and bd-x (Boise et al., 1993). p53 can bind directly to the promoter of the bax gene leading to vigorous transactivation of reporter gene constructs (Miyashita and Reed, 1995). Hence, the bax gene is a credible p53 target in selected apoptotic pathways (F armer et al., 1992; Miyashita et al., 1994; Selvakumaran et al., 1994; Sabbatini et al., 1995; Yonish-Rouach et al., 1995).

Bax overexpression causes mitochondrial release of several death factors, resulting in the activation of caspases that degrade cytoskeletal support (Green and Reed, 1998; Susin et al, 1999). Such cytoskeletal changes contribute to some of the classical morphologic signs of apoptosis (Mills et al., 1998), a common mode of programmed cell death orchestrated by intracellular death programs (Kerr et al., 1972; Cummings et al., 1997). These morphologic signs include the margination and condensation of nuclear chromatin (pyknosis), cytoplasmic shrinkage, membrane blebbing, and breakdown of the cell into apoptotic bodies. Theaccompanying fragmentation of nuclear DNA at nucleosomal boundaries has long been regarded as one of the biochemical hallmarks of the execution phase of apoptosis (Wyllie et al., 1980; Ucker et al., 1991). In agarose gels, one obtains a ladder of DNA fragments sized as multiples of the $\approx 180$ base pair nucleosomes. TdT-mediated dUTPbiotin nick end labeling (TUNEL) stains these DNA fragments in standard procedures to local ize apoptotic cells in situ (Gavrieli et al., 1992; Ansari et al., 1993; Gorczyca et al., 1993; Coates et al., 1994).

In the present study of cell death in renewing epithelium, we wanted to examine cutaneous programmed cell death in the absence of the cellular complexity of hairy skin or the pathological complexity of sunlight-stressed, aged skin (Ren et al., 1996). Thus, we chose to examine young mice whose lingual epithelium comprises a benign environment for both squamous and gustatory epithelial cells. We examined the vallate gustatory papilla present on the posterior one-third of the mouse tongue, wheretaste buds are situated in two dorsal trenches that protect them against serious mechanical injury.

Little is known about the death of aged squamous and gustatory (intragemmal) cells in the tongue. Whereas it has been reported that vallate taste cells die apoptotically after denervation, the minimum cell age and mode of death during normal turnover have been uncertain, because TUNEL-positive taste cells were rare occurrences (Takeda et al., 1996). N or has there been an examination of the molecular participants in the taste cell death pathway. Accordingly, the present investigation sought to discover the normal mode of lingual epithelial cell death and to identify putative molecular death factors in taste cells. We observed that 8-11\% of adult taste receptor cells contained p53, or Bax, or fragmented DNA, sometimes in conjunction with morphologic signs of apoptosis. The restriction of p53 and Bax to older receptor cells and their coexpression at the same neonatal age and in the same cells linked p53 and Bax as co-participants in taste cell apoptosis. The presence of p53 in postmitotic cells extends the role of p53 beyond stressed dividing cells.

As with olfactory receptor cells, the turnover of taste receptor cells carries the dear prospect of disrupting sensory signaling. Taste axons somehow must connect selectively with the appropriate replacement receptor cells. The present observations of the locations of aged taste cells within taste buds are pertinent to the puzzle of selective reconnection between axon and proper receptor cell (see Discussion).

\section{MATERIALS AND METHODS Tissue preparation}

The research protocol on mice was approved by the University of Michigan Animal Care and U se Committee in conformity with National Institutes of Health guidelines. Adult mice (6-16 weeks old) weighing 20-30 g were anaesthetized with sodium pentobarbital $(0.1 \mathrm{mg} / \mathrm{gram}$ body weight) and perfused intracardially with heparinized Ringer's solution followed by either $4 \%$ formaldehyde or acid alcohol (70\% ethanol, 10\% acetic acid). Neonatal mice [ages postnatal day 0 (P0) to P7] were killed with sodium pentobarbital $(0.1 \mathrm{mg} / \mathrm{gram}$ body weight). Their tongues were immersed in 4\% formaldehyde or acid alcohol fixative. Ten-micrometer-thick, transverse, frozen sections of the tongue were mounted on gelatin chrome alum-coated slides and stored at $-20^{\circ} \mathrm{C}$.

Adult p53 null mutant (p53-/-) mice from J ackson Laboratories (J R2103; Bar Harbor, ME; Donehower et al., 1992) were killed at 10 weeks $(n=1)$, at 18 weeks $(n=1)$, and at 20 weeks $(n=2)$. The mice were anaesthetized with sodium pentobarbital at $0.1 \mathrm{mg} / \mathrm{g}$ body weight and perfused intracardially with heparinized Ringer's solution followed by acid-alcohol fixative solution. The tongue was removed and postfixed in acid al cohol overnight.

\section{In situ TUNE L method for apoptotic cells}

The TACS TBL apoptosis detection kit from Trevigen, Inc. (Gaithersburg, MD) is the TUNEL method that was used to detect DNA fragmentation in $4 \%$ formaldehydefixed tissue sections. After a 10-minute rehydration in $0.1 \mathrm{M}$ phosphate-buffered saline, $\mathrm{pH} 7.4$ (PBS) and $0.4 \%$ Triton X-100 (TX100; Sigma Chemical, St. Louis, MO), the sections were treated with a $1: 50(20 \mu \mathrm{g} / \mathrm{ml})$ or $1: 200$ dilution of protease $K$, followed by 4 minutes of $0.3 \%$ hydrogen peroxide blocking solution, and a 1-hour incubation in a solution of terminal deoxynucleotidyl transferase and biotinylated deoxynucleoside triphosphates (dNTPs) at $37^{\circ} \mathrm{C}$ in a humidified chamber. The reaction was stopped by immersing the slides in stop buffer for 5 minutes followed by two 4-minute rinses of deionized distilled water. A dilution of 1:500 streptavidin-horseradish peroxidase (HRP) was applied for 10 minutes. Four 2-minute washes in deionized water preceded the 5-minute application of the TACS Blue reagent. The sections were counterstained with a proprietary red dye. Reducing the protease $\mathrm{K}$ concentration to 1:200 improved tissue preservation while retaining most of the staining intensity. This Trevigen kit included slides prepared with smears of normal 
and apoptotically stressed ML-1/Wif1 cells for use as method controls.

\section{Quantitative measurements of relative cell abundance}

A taste bud with the modal diameter of 35-40 $\mu$ m can be spanned by four $10-\mu \mathrm{m}$-thick sections. Each of the larger sections through a taste bud was defined as a taste bud profile. Based on nuclear counts of 40 taste bud profiles with nuclei stained with bisbenzamide (see below), a vallate taste bud profile contains a mean of $27 \pm 4$ taste cells (mean \pm 1 S.D.). This is consistent with the mean value of 92 cells per mouse vallate taste bud obtained from the analysis of serial sections of taste buds examined with a high-voltage electron microscope (Kinnamon et al., 1988). Comparisons across death factors of the percentage of cells stained in samples of at least 100 profiles are independent of the mean cells per taste bud profile, because this factor of 27 cells/profile was constant for all percentage calculations.

\section{Immunocytochemistry for p53, B cl-2 family factors, and keratin 8}

The standard immunocytochemical procedure used an avidin-biotin-peroxidase complex (ABC; Vector Laboratories, Burlingame, CA) and 3,3'-diaminobenzidine (DAB, Sigma). Mounted, acid alcohol-fixed tissue sections were rehydrated in four 4-minute washes of 0.1 M PBS, pH 7.4, containing $0.4 \%$ TX 100 . The slides subsequently were incubated for 30 minutes with 3\% normal goat serum (Sigma or Cappel Organon Teknika, Durham, NC) in PBS followed by a 1-hour incubation with the primary antibody at room temperature. The slides were washed with PBS four times followed by a 45-minute application of the biotin-conjugated secondary antibody. Three additional washes in PBS preceded both the 30-minute application of $A B C$ and the 10-minute incubation with a PBS solution containing $0.5 \mathrm{mg} / \mathrm{ml} \mathrm{DAB}, 0.01 \% \mathrm{H}_{2} \mathrm{O}_{2}$, and $0.04 \% \mathrm{NiCl}_{2}$ to tint the reaction product blue. Tofacilitate cell counting, after two additional washes in PBS, the slides were stained by 1:1,000 bisbenzami de (H oechst B-33258; Sigma), dehydrated with a series of ethanol solutions, and coverslipped with DPX (BDH Ltd., Poole, England). Nuclei were counted in the major sections through taste buds-the taste bud profiles.

\section{Primary antibodies and biotinylated secondary antibodies}

Anti-Bcl-2. The primary anti-Bcl-2 antibodies were hamster anti-mouse Bcl-2 monoclonal antibody (mAb) at a dilution of 1:100 (clone 3F 11; PharMingen, San Diego, CA; also a gift from $\mathrm{G}$. Nuñez), rat anti-mouse Bcl-2 mAb (1:50; clone 4C11; a gift from G. Nuñez), hamster anti-human $\mathrm{B} \mathrm{cl}-2$ mAb (1:100; clone 6C8; PharMingen; also a gift from G. Nuñez), mouse anti-human Bd-2 mAb (1:50; clone 124; Dako Co., Carpenteria, CA), and rabbit anti-mouse $\mathrm{BCl}-2$ polyclonal antiserum (1:1,000; 15616E ; PharMingen). The secondary antibodies were goat anti-hamster immunoglobulin G (IgG; 1:100; Caltag Laboratories, Burlingame, CA), goat anti-rat IgG (1:200; J ackson I mmunoresearch, West Grove, PA), goat anti-mouse IgG (1:200; Sigma; Vector Laboratories), and goat anti-rabbit IgG (1:200; Santa Cruz Inc., Santa Cruz, CA; Sigma).

Anti-Bcl-x. The anti-BCl-x primary antibodies were mouse anti-rat $\mathrm{Bcl}-\mathrm{x}$ mAb (1:50; clone 4; Transduction Laboratory) and rabbit anti-human Bd-x polyclonal antise- rum (1:1,000; B22630; Transduction Laboratory). These react with both $\mathrm{BCl}-\mathrm{x}_{\mathrm{L}}$ and $\mathrm{BCl}-\mathrm{x}_{\mathrm{S}}$. The secondary antibodies weregoat anti-mouse IgG (1:200; Sigma; Vector Laboratories) and goat anti-rabbit I gG (1:200; Sigma; Santa Cruz Inc.).

Anti-p53. Mouse anti-human p53 mAb (1:100; clone 240; PharMingen) was used as the primary anti-p53 antibody. Less effective was mouse anti-murine p53 mAb (1:100; clone 246; Santa Cruz Inc.). The secondary antibody was goat anti-mouse IgG (1:200; Sigma; Vector Laboratories).

Anti-Bax. The primary anti-Bax antibodies were rabbit anti-mouse Bax polyclonal antiserum (1:200; sc-526; Santa Cruz I nc.) and rat anti-mouse Bax mAb (1:100; clone G206-1276, PharMingen). The secondary antibodies were goat anti-rabbit IgG (1:100; Santa Cruz Inc.) and goat anti-rat I gM (1:200; J ackson I mmunoresearch).

Anti-keratin 8. The mAb Troma-I (1:60; Hybridoma Bank, University of I owa, I owa City, IA) readily identified all taste receptor cells by its reaction with keratin 8 (Zhang et al., 1997). The secondary antibody used was goat anti-rat IgG (1:1,500; J ackson I mmunoresearch).

\section{Fluorescence double-labeling for $\mathrm{p} 53$ and $\mathrm{Bax}$}

After treatment with $0.3 \% \mathrm{H}_{2} \mathrm{O}_{2}$ and $3 \%$ normal goat serum as blocking agents for 6 minutes and 30 minutes, respectively, the tissue sections went through the following sequence of reagents interspersed with four 4-minute rinses in 0.1 M PBS: 1:100 anti-mouse Bax (1 hour of rat IgM mAb; PharM ingen), 1:100 biotin-conjugated goat antirat IgM secondary (45 minutes), $1.5 \mu \mathrm{g} / \mathrm{ml}$ streptavidinTexas red (30 minutes; GIBCO BRL, Cleveland, OH), 1:100 anti-human p53 (1 hour; mouse IgG mAb; PharMingen; Santa Cruz), and 1:200 fluorescein isothiocyanate (FITC)conjugated goat anti-mouse IgG (1 hour). The sections were visualized with fluorescence microscopy. The Baxlabeled cells were red, and the p53-reactive cells were green. There was no cross reaction between the Bax primary antibody and the FITC-conjugated goat antimouse IgG or between the p53 antibody and streptavidinTexas red. Double-staining failed after omission of either primary antibody or either the streptavidin-Texas red or the FITC-conjugated secondary antibody.

\section{Double-labeling for 5-bromo-2'-deox yuridine and Bax}

Sixteen adult mice were injected intraperitoneally with 5-bromo-2'-deoxyuridine (BrdU) at $0.5 \mathrm{mg} / \mathrm{mouse}$ (Sigma) and killed at daily intervals. Three litters of newborn mice (25 pups) were injected intraperitoneally with BrdU at $0.05 \mathrm{mg} / \mathrm{mouse}$, and individual mice were killed daily until P8. After denaturation of DNA with $2 \mathrm{~N} \mathrm{HCl}$, the tissue underwent immunocytochemical staining. I ncubation with anti-BrdU antibody (1:20; Accurate Chemical \& Scientific Co., Westbury, NY) for 1 hour was followed by the secondary antibody, biotin-sp-conjugated goat anti-rat IgG (1: 1,000; J ackson Immunoresearch). The BrdU was visualized with the $A B C / D A B$ sequence. After four 4-minute rinses with $\mathrm{PBS}$, the sections were stained for Bax immunoreactivity by using $A B C / D A B$ without the nickelchloride solution. This made the Bax-positive cells yellowbrown, and the BrdU-labeled nuclei were blue. Attempts to double label for p53/TACS or p53/BrdU were technically unsatisfactory. Adobe PhotoShop software (Adobe Sys- 
tems, Mountain View, CA) was used to merge and label the 12 subparts of Figure 1 .

\section{RE SULTS \\ Some taste receptor cells and neighboring squamous cells were TUNE L positive}

The TUNEL method (TACS) labeled the nuclei of some el ongated cells of taste buds (intragemmal receptor cells) and some ordinary squamous epithelial cells of adult mouse tongue (Fig. 1A-C). Basal cells were unstained. Scattered within the intermediate layer and more abundantly within the superficial layer were TUNEL-positive squamous cells. (Fig. 1A). Despite its high sensitivity, it is unlikely that TUNEL stained healthy cells spuriously. F or example, compared with adults, the lingual epithelium of P1 mice had only a few positive nuclei. I n a method control, less than $2 \%$ of cultured ML1/Wif1 control cells were stained (Fig. 1D), whereas, of the cells that had been subjected previously to serum withdrawal, more than $50 \%$ became TUNEL positive (data not shown). The TUNEL protocol led to some tissue degradation that limited the numbers of taste bud profiles that were useful for quantitating the incidence of apoptotic intragemmal cells. Nine well-preserved taste bud profiles contained an average of about two positive cells per taste bud profile, equivalent to nearly $8 \%$ of the intragemmal cells. These TUNELpositive cells were scattered within the taste bud and did not have a preferred location, such as the bud's perimeter or core.

\section{Taste cells and squamous cells from adults and neonates were immunonegative for $\mathrm{BCl}-2$ and $\mathrm{BCl}-\mathrm{x}_{\mathrm{L} / \mathrm{S}}$}

Four mAbs against $\mathrm{Bcl}-2$ were ineffective in staining either adult or developing mouse vallate papilla and lingual epithelium. A Bcl-2 polyclonal antiserum produced tongue staining that was weak, widespread, and evenly nonspecific. Control sections from embryonic day 17 (E 17) mouse brain were immunopositive with mAb 3F 11 against $\mathrm{Bcl}-2$ (data not shown). The $\mathrm{Bd}-\mathrm{x}_{\mathrm{L} / \mathrm{S}}$ polyclonal antiserum also stained the E17 mouse brain (data not shown); however, neither the mAb nor the polyclonal antiserum against $\mathrm{BCl}-\mathrm{x}_{\mathrm{L} / \mathrm{S}}$ was effective in staining either the mouse vallate papillae or the neighboring squamous epithelium. This lack of specific $\mathrm{BCl}-2$ and $\mathrm{BCl}-\mathrm{x}_{\mathrm{L} / \mathrm{S}}$ immunostaining of the lingual epithelium does not preclude the presence of these factors at low levels or the presence of other $\mathrm{Bcl}-2$ family survival factors. However, these results did focus our inquiry on death factors in the Bcl-2 family.

\section{Lingual Bax staining localized to taste cells}

The presence of simple keratins allows one to distinguish precisely the differentiated taste receptor cells from neighboring immature taste cells or squamous epithelial cells (Knapp et al., 1995). For example, mAb Troma I stained keratin 8 in most, if not all, mature taste receptor cells (Fig. 2A). Lingual Bax was localized exclusively to a subset of these intragemmal cells that, more frequently than in unstained cells, showed recognizable apoptotic characteristics, such as cell membrane projections (blebbing) or nuclear disruption (Fig. 2D,F,G, arrowheads). Scattered Bax-positive intragemmal cells could be found from the margin to the core of taste buds (Fig. 2B). An occasional, abnormally oriented, Bax-positive, el ongated cell lay beneath the basal lamina outside of the taste bud (F ig. 2E ). Such cells may have failed to enter the taste bud. Omission of the Bax antibody eliminated staining (Fig. $2 \mathrm{H})$.

The relative abundance of Bax-positive taste cells was determined by counting stained cells in the one to three largest sections of each vallate taste bud in six adult mice. Assuming that there were 27 cells per taste bud profile (see Table 1 and Materials and M ethods, above), 10.3\% $\pm 0.8 \%$ of taste cells were Bax positive in adult vallate papillae (Table 1).

\section{Lingual p53 staining localized to taste cells}

In the tongue, the only cells specifically stained by either of two mAbs against the tumor suppressor protein p53 were elongated cells scattered within vallate taste buds (Fig. 3). Although some nuclei were immunoreactive (Figs. 3B,D, 4E ), p53 staining of intragemmal cells was predominantly cytoplasmic. Some p53-expressing intragemmal cells had nuclear condensation or membrane blebbing that are established characteristics of apoptosis (Fig. 3D,F, arrowheads). Membrane blebbing in p53-positiveand Baxpositive cells was easier to resolve than in the nearby immunonegative cells, in which it appeared less common. The p53-positive intragemmal cells occupied varied radial positions within the taste bud (Fig. 3B,D). Occasionally, a polygonal cell at the base of the taste bud was stained (Fig. 3E). Omission of the primary antibody eliminated specific staining (Fig. 3G). The absence of stained cells in p53-1mice established the specificity of the p53 antibody (Fig. $3 \mathrm{H}$ ). Counts of the abundance of p53-positive taste cells in vallate taste buds in four adult wild-type mice indicated that $11.4 \% \pm 1.1 \%$ of intragemmal taste cells were p53positive (Table 1).

\section{p53 and Bax were coexpressed in neonatal taste cells}

We examined $\mathrm{p} 53$ and Bax expression in vallate taste cells of neonatal mice ages P0-P7. There were no p53positive or Bax-positive cells at $\mathrm{P} 0$, when the vallate contains numerous immature taste buds and $19 \pm 4$ taste buds with several differentiated cells (Cooper and Oakley, 1998). The first appearance of p53 or Bax was in an occasional polygonal vallate cell at P1 (Fig. 4A,B). Elongated p53-positive or Bax-positive intragemmal cells were evident first by P2 (Fig. 4C,D). By P4, several of the numerous taste cells were Bax positive (Fig. 4G,H).

In double-labeling experiments carried out at P5 and P7, more than half of the stained cells were immunopositive for p53 and Bax (Table 2). In some P5 mouse vallate sections, the only cell that was stained was positive for both p53 and Bax (Fig. 1E-G). Adult taste buds had numerous double-labeled intragemmal cells as well as others that were singly labeled either for Bax or for p53 (Fig. 1H).

\section{BrdU and Bax were coexpressed in intragemmal cells in mature and immature taste buds}

BrdU-positive intragemmal cells were first evident 1 day after BrdU injection. However, neither adult nor neonatal BrdU-positive intragemmal cells expressed Bax until 5 days after BrdU injection (Fig. 1J ,K). For example, neonatal taste cells born on $\mathrm{PO}$ were never Bax positive before P5. Neonatal intragemmal cells colabeled for Bax and BrdU were observed from 5-7 days after BrdU injec- 

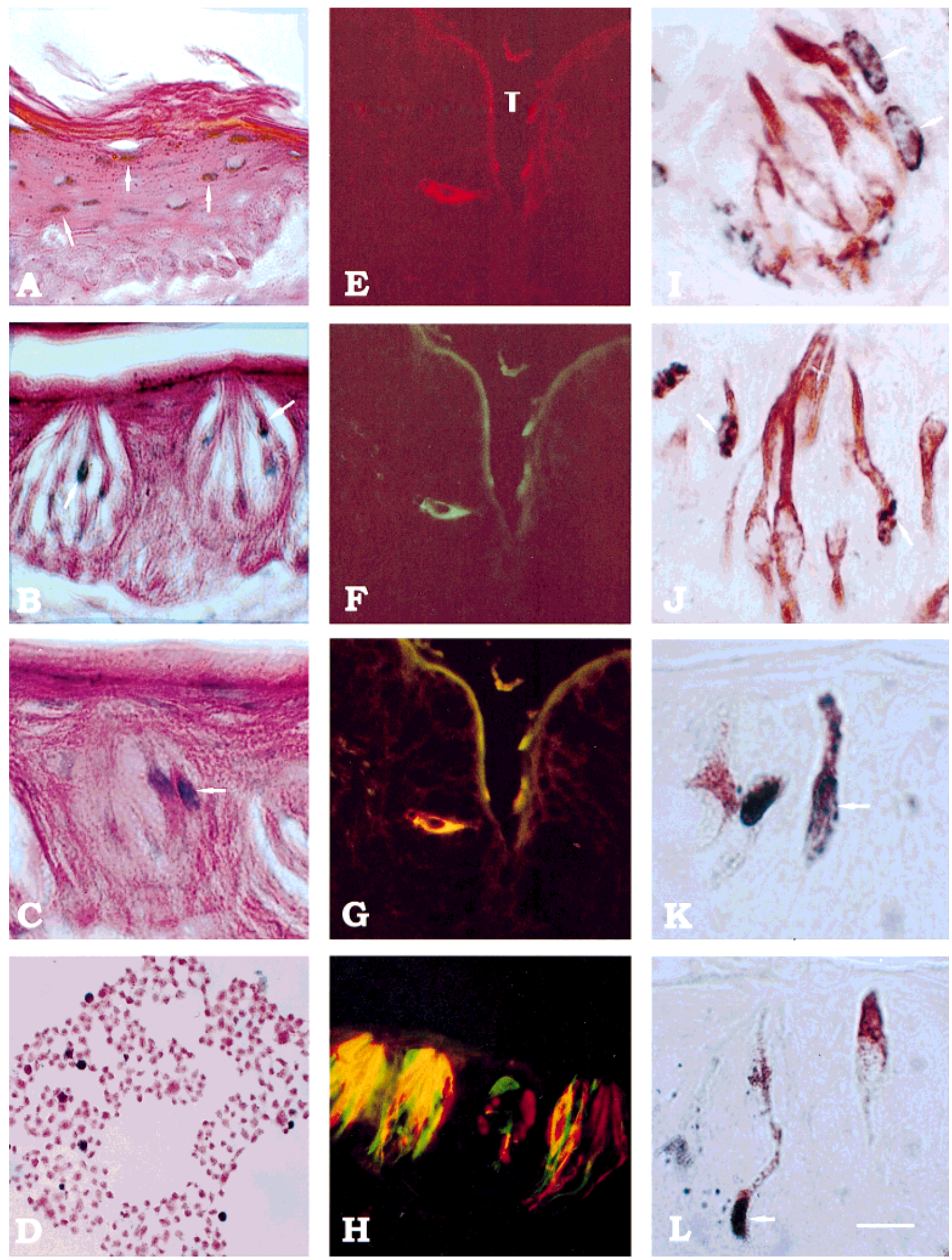

Figure 1 


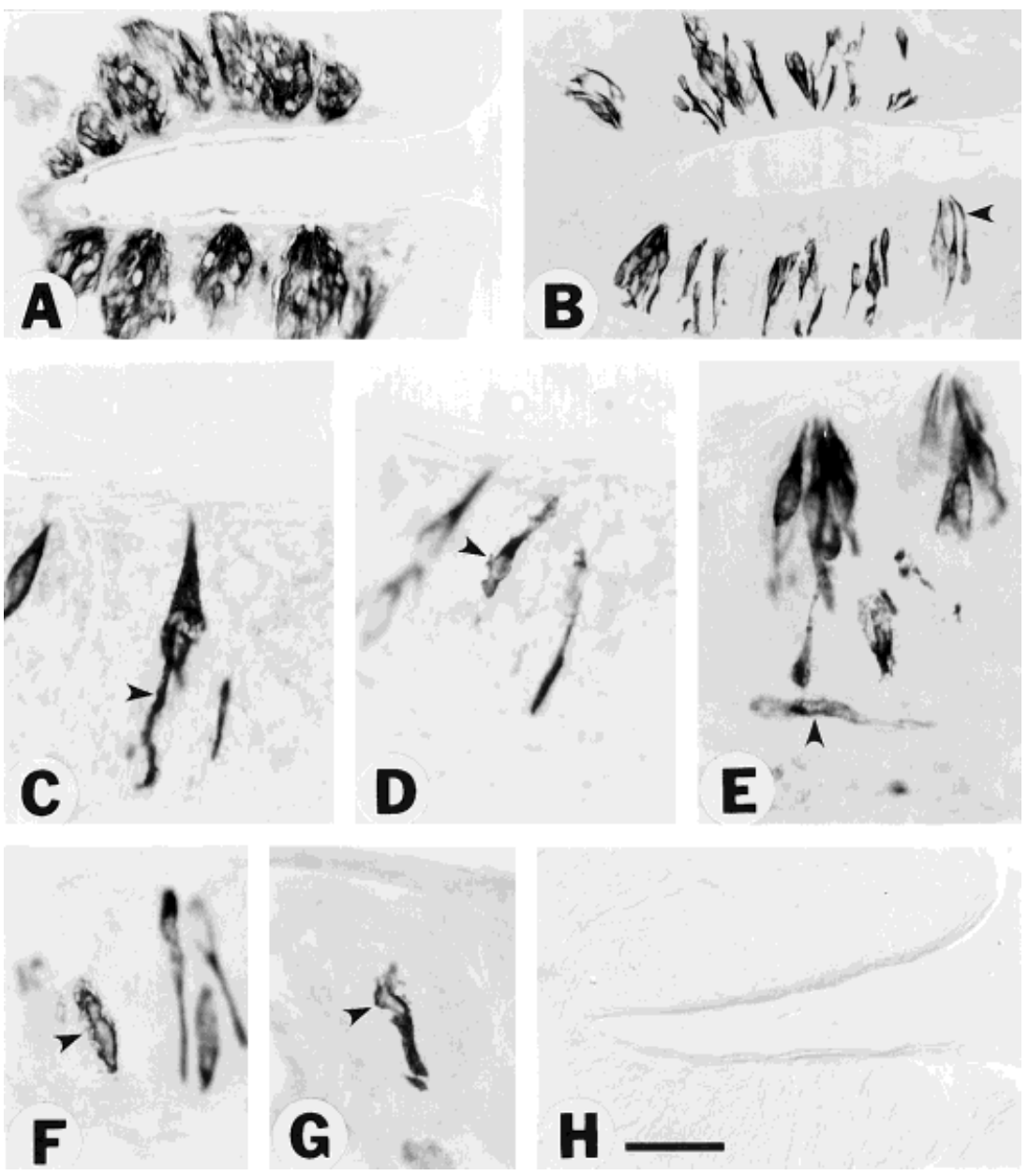

Fig. 2. Bax is expressed in adult mouse vallate taste buds in $10-\mu \mathrm{m}$-thick frozen sections. A: Staining of a vallate trench wall for keratin 8 reveals multiple taste buds. B: Bax-positive intragemmal cells are present in taste buds of an adjacent section. Bax expression extends throughout the cytoplasm, including apical processes (arrow- head) and basal processes. C-G: Bax immunoreactivity of taste cells at higher magnification. Several intragemmal cells had cell membrane distortions, nuclear shrinkage, or fragmentation (C,D,F,G, arrowheads). The arrowhead in $\mathrm{E}$ indicates a displaced intragemmal cell. H: Control with no primary antibody. Scale bar $=40 \mu \mathrm{m}$ in A,B,H, $16 \mu \mathrm{m}$ in C-G.

TABLE 1. Incidence of p53-Positive and Bax-Positive Taste Cells in Wild Type and p53-1- Vallate Papillae

\begin{tabular}{|c|c|c|c|c|}
\hline $\begin{array}{l}\text { Genotype and } \\
\text { no. of mice }\end{array}$ & $\begin{array}{l}\text { Mean taste bud } \\
\text { profiles examined } \\
\text { in adult vallate }\end{array}$ & $\begin{array}{c}\text { Mean of all } \\
\text { intragemmal cells } \\
\text { in taste bud profiles }\end{array}$ & $\begin{array}{l}\text { Mean no. of cells that } \\
\text { were immunoreactive } \\
\text { among all cells examined }\end{array}$ & $\begin{array}{c}\text { Percentage of } \\
\text { intragemmal cells that were } \\
\text { immunoreactive (column 4/column 3) }\end{array}$ \\
\hline $\begin{array}{l}\text { Wild type }(n=4) \\
\text { Wild type }(n=6) \\
\text { p55-l- }(n=2)\end{array}$ & $\begin{array}{l}197 \pm 65 \\
248 \pm 34 \\
339 \pm 10\end{array}$ & $\begin{aligned} 5,319 & \pm 1,754 \\
6,696 & \pm 923 \\
11,187 & \pm 327\end{aligned}$ & $\begin{aligned} 605 & \pm 202 \text { (p53 reactive) } \\
690 & \pm 135 \text { (Bax reactive) } \\
1,365 & \pm 72 \text { (Bax reactive) }\end{aligned}$ & $\begin{array}{l}11.4 \pm 1.1 \\
10.3 \pm 0.8 \\
12.0 \pm 0\end{array}$ \\
\hline
\end{tabular}

${ }^{1}$ Vallate intragemmal cells were examined for $\mathrm{p} 53$ immunoreactivity in four wild type mice ages 14-21 weeks and examined for Bax immunoreactivity both in six wild type mice ages 12-20 weeks and in two p53-l- miceages 18 weeks and 20 weeks. In serial sections of normal vallate, taste bud nuclei that were stained with bisbenzamide were counted. A sample of 40 well-preserved wild type taste buds had a mean of $27 \pm 4$ taste cells/taste bud profile, whereas a sample of $37 \mathrm{p} 53^{-1-}$ taste buds had a mean of $33 \pm 5$ taste cells/taste bud profile The number of taste bud profiles examined was multiplied by the average of 27 cells (or 33 cells in p53- $3^{-1}$ mice) to give the total number of intragemmal cells examined, as shown in column 3 , representing means of two to six mice. Entries are means \pm 1 standard deviation.

Fig. 1. TdT-mediated dUTP-biotin nick end labeling (TUNEL) labeled the nuclei of some cells in mouse tongue. A: The dark blue nuclei of apoptotic cells are present in ordinary squamous epithelial cells (arrows). B,C: Some intragemmal cells were TUNEL-positive in vallate taste buds (arrows; optics were adjusted to emphasize cell surfaces to show that the positive cells were elongated). D: In this control slide of normal ML-1/Wif1 cells, about eight cells were apoptotic (large dark blue nuclei), and the rest were viable. E-G: In a section through a postnatal day 5 (P5) vallate trench (T), a single intragemmal cell immunopositive to $\mathrm{Bax}(\mathrm{E})$ is also positive to $\mathrm{p} 53(\mathrm{~F})$, as shown in a double exposure (G). $\mathbf{H}$ : Another double-stained section of adult vallate taste buds has p53-positive (green), Bax-positive (red), and double-labeled (gold) intragemmal cells. I-L: Bax and 5-bromo-2'deoxyuridine (BrdU) double labeling in taste buds of adult and young mice. I: In this adult mouse vallate taste bud that was examined 4 days after intraperitoneal injection of BrdU, the two cells positive for BrdU were negative for Bax (arrows). J: Five days after BrdU injection, two elongated, Bax-positive taste cells had BrdU-positive nuclei (arrows). K: Mouse that received an intraperitoneal injection of BrdU at P0. By P5, a vallate intragemmal cell was double stained for BrdU and Bax (arrow). L: At P7, a Bax-positive intragemmal taste cell had a BrdU-positive nucleus (arrow). A taste cell single-label ed for Bax is also shown. Scale bar $=30 \mu \mathrm{m}$ in A,D, $16 \mu \mathrm{m}$ in B, $12 \mu \mathrm{m}$ in C, $18 \mu \mathrm{m}$ in $\mathrm{E}-\mathrm{H}, 10 \mu \mathrm{m}$ in $\mathrm{I}-\mathrm{L}$. 

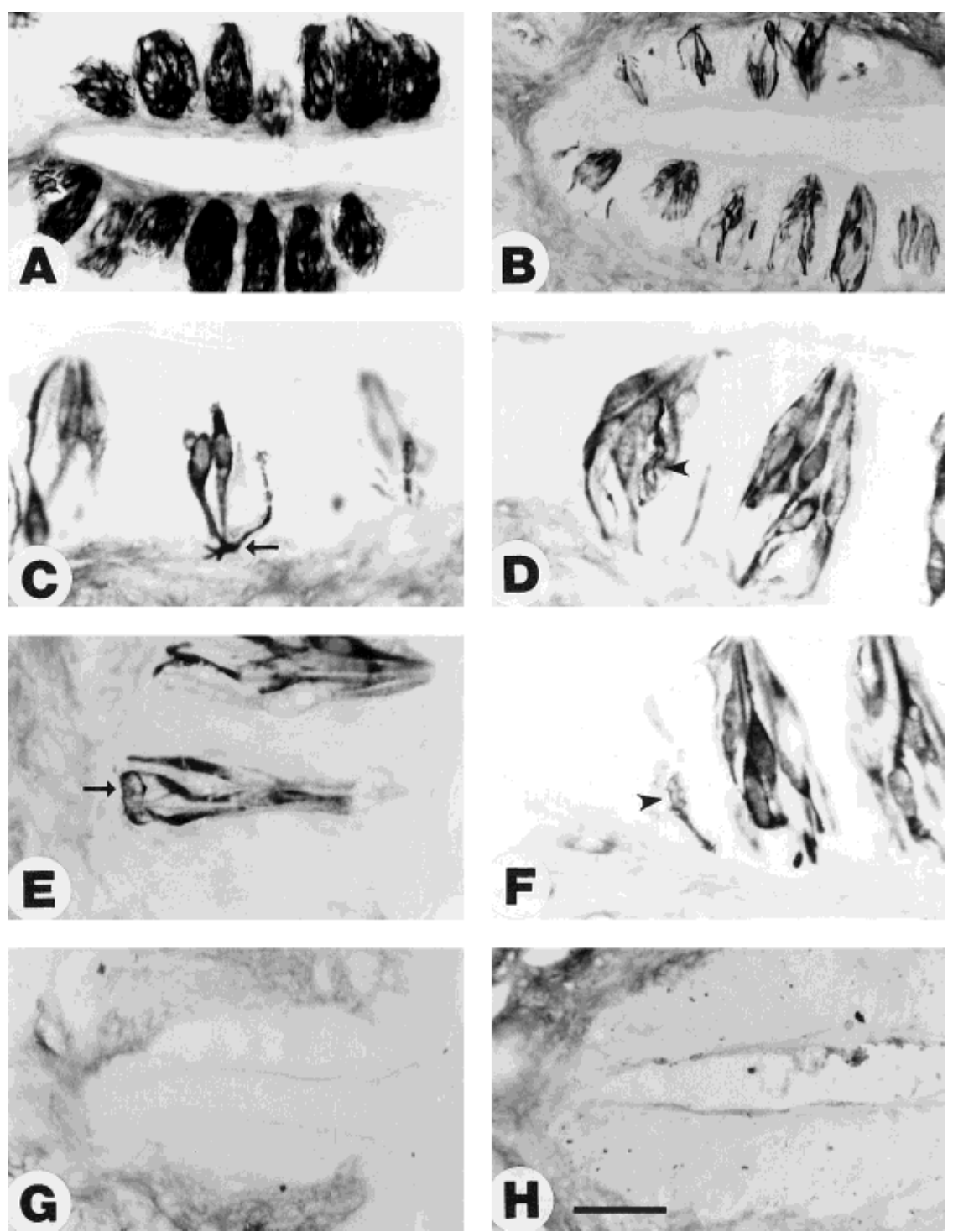

Fig. 3. p53 was expressed in adult vallate taste buds. A: All intragemmal cells in mouse vallate taste buds were immunoreactive for keratin 8. B: In an adjacent section, a subset of intragemmal cells was p53 immunoreactive. The nonspecific staining outside the vallate trench was due to the goat anti-mouse secondary antibody, as evident in the no primary antibody control in G. C-F: The apical and basal cytoplasm of several intragemmal cells is p53 immunopositive. Even the most basal processes can be immunoreactive (C, arrow). The

tion (Fig. 1L). It is likely this Bax expression in middleaged cells (5- 6 days old) is a response to the high sensitivity of taste cells to BrdU toxicity (Zhang et al., 1995). This indicates that, when they are stressed, some taste cells will express Bax. Omission of the BrdU injection or of the primary or secondary antibody eliminated the specific staining for BrdU and Bax, respectively.

\section{Taste cells and Bax expression in adult p53- mouse vallate}

Troma I revealed that the morphology and abundance of vallate taste buds was similar in wild type mice (Fig. $3 \mathrm{~A}$ )

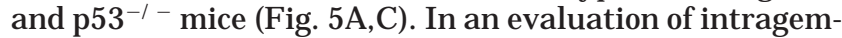
mal cell abundance, bisbenzamidenuclear staining showed

arrowheads in $D$ and $F$ indicate intragemmal cells with nuclear shrinkage and membrane blebbing, respectively. The arrow in $\mathrm{E}$ reveals an oddly positioned p53-positive polygonal cell at the base of the taste bud. G: Omission of the primary antibody (anti-p53) eliminated staining. $\mathbf{H}$ : There were no immunoreactive cells in the vallate trench wall of a p53 null mutant mouse. Scale bar $=40 \mu \mathrm{m}$ in A,B,H, $80 \mu \mathrm{m}$ in $\mathrm{G}, 16 \mu \mathrm{m}$ in $\mathrm{C}-\mathrm{F}$.

that vallate taste bud profiles in $\mathrm{p} 53^{-1-}$ mice had an average of $33 \pm 5$ taste cells ( $n=37$ profiles) compared with $27 \pm 4$ cells/profile in wild type mice $(n=40$ profiles; Table 1).

Two adult p53-1- mice had numerous Bax-positive vallate intragemmal cells (Fig. 5B,D-F). Some of these cells had apoptotic features, like membrane blebbing and nudear shrinkage (Fig. 5D). Bax-positive, elongated taste cells were located beneath the basement membrane of the vallate trench wall more often than in wild type mice (five or six vs. three or four displaced cells per serially sectioned vallate; Fig. 5D-F). Perhaps a greater density of taste cells excluded some cells from the taste bud. The percentage of

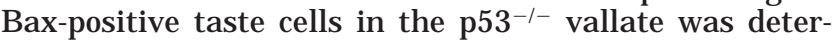




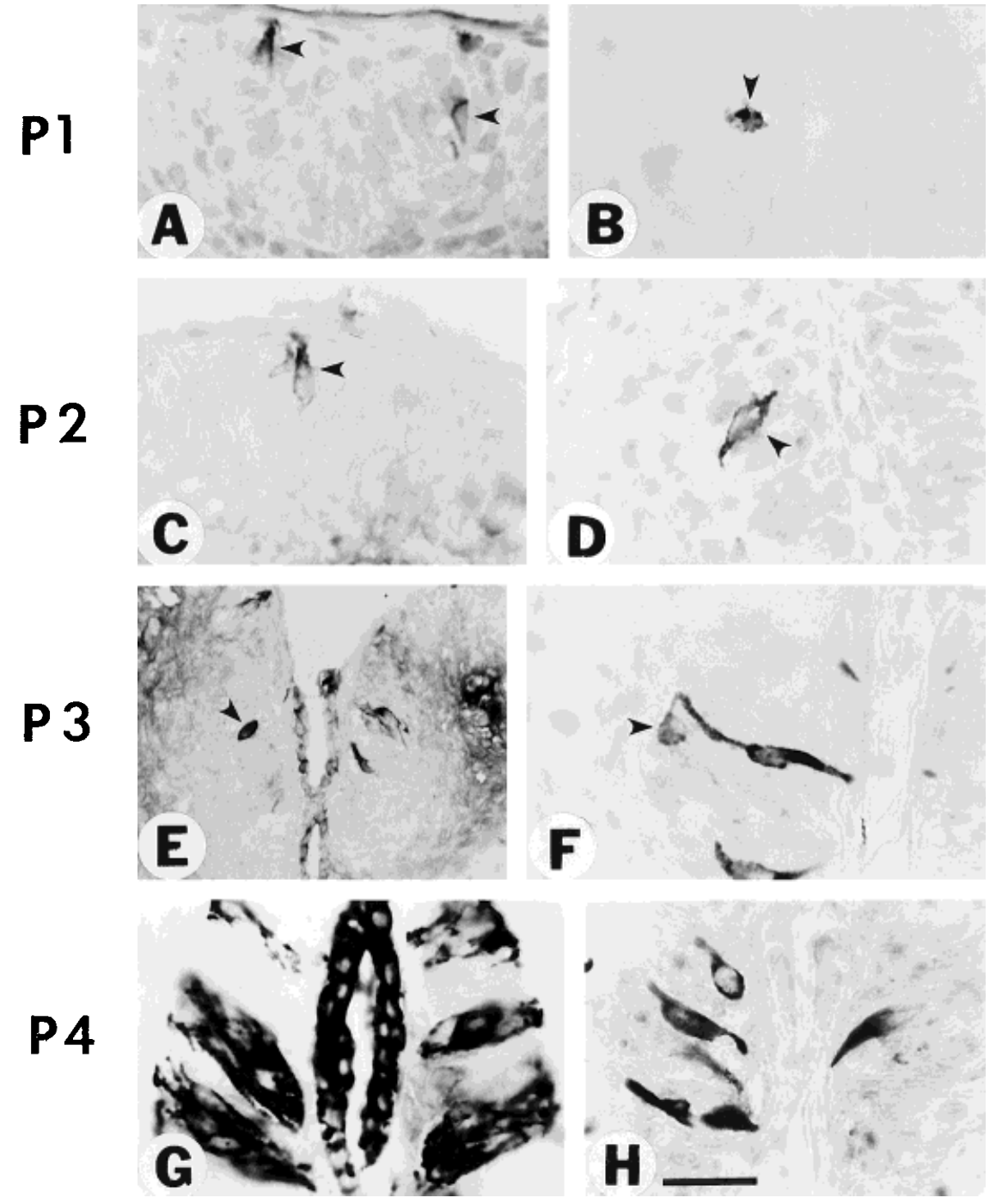

Fig. 4. A few taste cells were p53 and Bax immunoreactive in P1-P3 mouse vallate papillae. Vallate sections were stained for Bax $(B, D, F, H)$ or for p53 (A,C,E; keratin staining is shown in $G$ ). A: Arrowheads indicate p53-positive cells associated with taste buds near the dorsal surface of the P1 vallate papilla. B: Arrowhead demonstrates a polygonal Bax-positive cell in the $\mathrm{P} 1$ vallate papilla. C,D: Some el ongated cells were p53 positive (C, arrowhead) and Bax positive (D, arrowhead). E: Arrowhead indicates a p53-positivenucleus

mined by examining the two or three largest sections through each taste bud. The proportion of taste cells that were Bax positive in p53-1- mice was at least equal to that in wild type mice, as assessed with the same methods (12\% vs. 10.3\%; Table 1). Hence, p53 deficiency did not reduce Bax expression and may have increased it.

\section{DISCUSSION C 0 -expression of p53 and Bax by old, dying taste cells}

BrdU/Bax double labeling demonstrated that only cells at least 5 days old expressed Bax, probably in response to BrdU toxicity (Zhang et al., 1995). Similarly, it was unusual for the young taste cells present in the first in a P3 mouse vallate. F: Elongated Bax-positive taste cell is present at P3. The arrowhead reveals a small, polygonal Bax-positive cell at the base of the taste bud (trench at far right). G,H: Adjacent sections of a P4 mouse vallate papilla were stained for keratin $8(\mathrm{G})$ and $\mathrm{Bax}(\mathrm{H})$. The large, dark, vertical oval centered in $\mathrm{G}$ is composed of keratin 8-positive salivary duct cells that line much of the neonatal vallate trench. Salivary duct cells were Bax negative. Scale bar $=40 \mu \mathrm{m}$ in E, $16 \mu \mathrm{m}$ in A-D, F-H.

neonatal week to be Bax positive, p53 positive, or TUNEL positive. No newborn mouse had p53-positive or Baxpositive vallate taste cells. At P7, if it is conservatively assumed that the average taste bud had accumulated only $25 \%$ of its adult complement of cells (Hosley and Oakley, 1987), the vallate would contain 2,300 intragemmal cells (23 cells/bud $\times 100$ taste buds). Hence, based on the immunostaining summarized in Table 2, no more than $1 \%$ of the 2,300 P7 taste cells were immunopositive either for p53 or Bax, in contrast to an 8-11\% incidence of these factors in adult vallate taste buds. Because $>90 \%$ of vallate intragemmal cells form after birth (Hosley and Oakley, 1987; Oakley et al., 1991; Cooper and Oakley, 1998), it is likely that a mouse at $P 7$ would have only a few vallate intragemmal cells as old as 9 days-the mean life 
TABLE 2. p53 and Bax I mmunoreactivity of Vallate Taste Cells ${ }^{1}$

\begin{tabular}{lcc}
\hline $\begin{array}{l}\text { Age (no. of } \\
\text { wild-type mice) and type of } \\
\text { immunoreactivity detected }\end{array}$ & $\begin{array}{c}\text { No. of } \\
\text { intragemmal } \\
\text { cells stained }\end{array}$ & $\begin{array}{c}\text { Immunoreactive } \\
\text { intragemmal cells } \\
\text { given as a percentage } \\
\text { of all cells stained }\end{array}$ \\
\hline P5 $(n=2)$ & 2 & 13 \\
p53 only & 1 & 6 \\
Bax only & 13 & 81 \\
p53 and Bax & 16 & 100 \\
Total & & 11 \\
P7 $(n=2)$ & 6 & 23 \\
p53 only & 13 & 66 \\
Bax only & 38 & 100 \\
p53 and Bax & 57 & 41 \\
Total & & 36 \\
Adult ( $=4)$ & & 23 \\
p53 only & 209 & 100 \\
Bax only & 186 & \\
p53 and Bax & 115 & \\
Total & 510 & \\
\hline
\end{tabular}

${ }^{1}$ Histologic sections of developing and adult vallate papillae were double stained to indicate the incidence of intragemmal cells that were immunoreactive either for p53 alone, for Bax alone, or for both. The number of stained intragemmal cells was counted in 134 taste bud profiles aggregated from four adult wild type vallate papillae and in serial sections of all vallate taste buds of two postnatal day 5 (P5) mice and two P7 mice ${ }^{2}$ Total cells stained were 16,57 , and 510 , as indicated. span of a taste cell (Takeda, 1979). Consequently, the scarcity of p53-positive or Bax-positivetaste cells in neonatal mice is explicable if both factors are expressed normally within older taste cells. When combined with these results on neonates, the observations that p53, or Bax, or fragmented DNA was present in $8-11 \%$ of adult receptor cells, sometimes in conjunction with morphologic signs of apoptosis, collectively implicate Bax in taste cell apoptotic death.

In the P7 vallate's population of $\approx 2,300$ intragemmal cells, 28 cells per mouse were positive for p53 and/or Bax. If p53 and Bax expression were independent events, then it is highly improbable that, out of 2,300 cells, as many as 19 of the 28 stained cells would have been double stained by chance $(P<0.001)$. Although it was not as common in adults, double labeling still was more frequent than predicted by chance (the proportion of all cells that were p53 positive $\times$ the proportion of all cells that were Bax positive $=0.09 \times 0.083=0.0075$ or $0.75 \%$ expected to be double labeled vs. 3.2\% observed; $\mathrm{P}<0.01 ; \chi^{2}$ test). Hence, these statistically significant coexpressions suggest that p53 is linked to Bax as part of an intragemmal cell death cascade (see below).
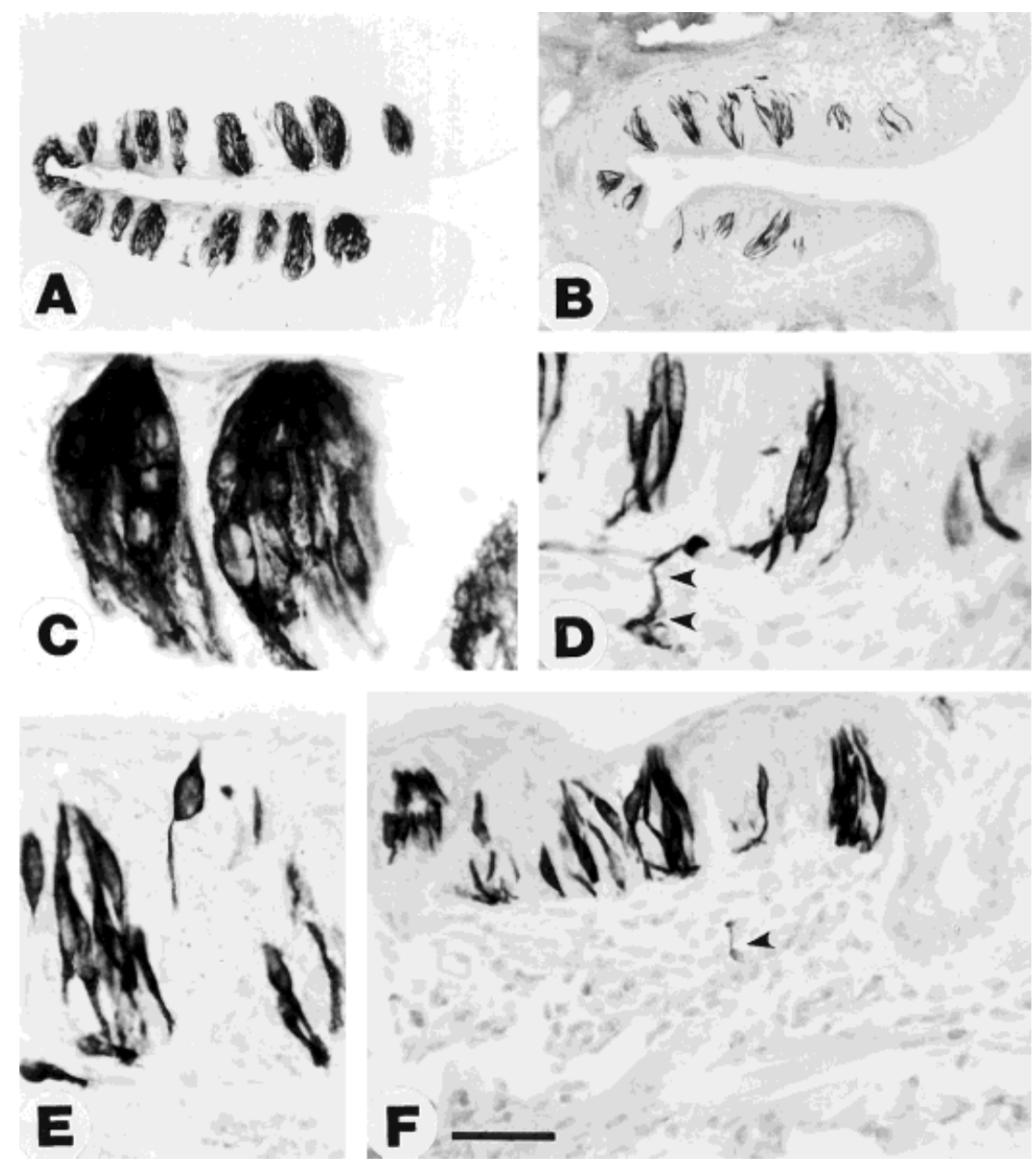

Fig. 5. A-F: Taste cells in p53 null mutant mice. Sections of adult p53 $3^{-1-}$ mouse vallate papilla were stained for keratin $8(A, C)$ or for Bax $(B, D-F)$. The arrowheads in $D$ indicate a Bax-positive intragemmal cell with a process that was abnormally directed basal to the tastebud.
One Bax-expressing intragemmal cell is positioned horizontally bel ow the base of the taste bud in $\mathrm{E}$. In F, the arrowhead indicates a portion of an elongated tastelike cell that was Bax positive and beneath the vallate papilla. Scale bar $=80 \mu \mathrm{m}$ in A,B, $16 \mu \mathrm{m}$ in C-E , $40 \mu \mathrm{m}$ in F. 


\section{E stimating the duration and order of putative gustatory apoptotic events}

Apoptosis can be divided into three sequential phases (J acobson et al., 1994). The induction phase uses signal transduction appropriate for the particular cell type. The commitment phase deploys death factors in the bcl-2 family and in the caspase family of proteases. The final or execution phase involves evolutionarily conserved degradation that includes nuclear condensation, pronounced membrane blebbing, and DNA fragmentation (Mills et al., 1998). Our results suggest the possibility that taste cells display these phases in three steps: p53 $\rightarrow$ Bax $\rightarrow$ DNA fragmentation. Accordingly, it is relevant to consider information on the temporal order and duration of p53 expression, Bax expression, and DNA fragmentation in taste cells.

We can approximate the duration of DNA fragmentation, p53 expression, and Bax expression as follows: With 92 cells per mouse vallate taste bud (Kinnamon et al., 1988) and a life span of 9 days (Beidler and Smallman, 1965; Takeda, 1979; Farbman, 1980), an average of ten taste cells should die each day. We estimated that the average taste bud had seven TUNEL-positive cells at a given time, suggesting that an intragemmal cell's fragmented DNA remained TUNEL detectable for $\approx 0.7$ days (the presumption that TUNEL-positive intragemmal cells are apoptotic has been confirmed by ultrastructural indices of apoptotic degeneration in TUNEL-positive, denervated taste cells; Takeda et al., 1996). A given taste cell may express $\mathrm{p} 53$ or Bax for about 1 day, because at least $9 \%$ of vallate intragemmal cells were p53 immunopositive, and at least $8 \%$ were Bax positive (these percentages were obtained from the experiments outlined in Table 2 that minimized double counts of taste cells). In comparison, Bax expression lasted 1-2 days in dying intestinal cells (Potten et al., 1997) and 2-3 days in neurons that were stressed by ischemia (Krajewski et al., 1995).

At P5 and P7, there was a high incidence of p53/Bax coexpression in taste cells. Moreover, p53 and Bax each were present first in taste cells on P1. The implied p53-Bax linkage may be direct, because Bax is a transcriptional target of p53. However, the consequences of p53 null mutation imply alternative pathways, because Bax expression did not require p53. With regard to the timing of events, DNA fragmentation occurred first at P2 (data not shown), 1 day after the first few intragemmal cells became Bax positive. This observation is consistent with the consensus view that DNA fragmentation and nuclear breakdown follow bax expression (Deckwerth et al., 1998; Green and Reed, 1998; Messan and Pittman, 1998). Thus, p53/Bax coexpression and the timing of apoptotic events in neonatal mice support the foll owing hypothetical sequence for aged, dying taste cells: p53 $\rightarrow$ Bax $\rightarrow$ DNA fragmentation. The paucity of TUNEL-stained, p53-positive, or Baxpositive neonatal taste cells suggests further that, if programmed cell death contributed significantly to taste bud development, then the signs of these deaths were undetected.

\section{Comparisons of p53 and Bax expression in taste buds, neurons, squamous epithelium, and intestine}

Bax helps kill developing neurons that fail to obtain sufficient neurotrophic support (White et al., 1998). The long life span of adult neurons may be attributed in part to the subsidence of Bax concentrations in the brain (Vekrellis et al., 1997) as well as to an increasing resistance of neurons to neurotrophin deprivation (Easton et al., 1997). Although p53 can contribute to the apoptosis of stressed neurons (Hughes et al., 1997), p53 was not detected in mature rat brain neurons. Instead, p53 was associated mainly with dividing and differentiating neurons and was not coexpressed with Bax (van Lookeren Campagne and Gill, 1998). In contrast, postmitotic older taste cells must have expressed p53, because Bax was restricted to middleaged and older taste cells, and, characteristically, p53 and Bax were coexpressed. F urthermore, unlikeneurons, developing taste cells have a low incidence of apoptosis, as judged by the paucity of Bax expression in young taste cells. These differences between Bax and p53 expression in neurons and mammalian taste receptor cells may reflect the markedly different life histories of these cells. Similar to what is seen in other renewing epithelia, taste cells are replaced after an average of 9-10 days, whereas brain neurons live long lives without ongoing replacement. Consequently, even though neurons use Bax during development and share neuron-specific enolase, synapses, and other traits with taste cells, the death pathways of neurons and taste cells appear different. Do taste cells share a standardized death pathway with other renewing epithelia?

Intestinal epithelium, vallate taste buds, and neighboring stratified squamous epithelium all are endodermally derived renewing epithelia (Zhang and Oakley, 1996). Intestinal villus cells, intragemmal cells, and stratified lingual cells are born at the base of their epithelia and subsequently move apically as they differentiate and die several days later (Potten et al., 1997). However, here again, despitesuch shared properties, thesevarious classes of renewing epithelial cells appear to follow diverse paths toward death. Bax, but not p53, is expressed in regions of cell death in intestinal crypts and in the colon (Krajewski et al., 1994; J ordan et al., 1996; Dekker et al., 1997; Maruoka et al., 1997; Potten et al., 1997). In both adult hairy skin and intestine, p53 is limited to a few cycling cells, whereas Bax, by contrast, is present in subsets of postmitotic, differentiated cells (Schmid et al., 1991; Spandau, 1994; Potten et al., 1997). Still different are squamous epithelial cells of the tongue that express neither Bax nor p53, whereas tastereceptor cells express both Bax and p53. Evidently, there is no standardized cell death pathway followed by renewing tissues ( acobson et al., 1997).

\section{Implications of p53 expression in postmitotic taste cells}

The activation of p53 is renowned in cells in which the DNA has been damaged by UV irradiation or other stressors. For example, p53 expression in pronounced in sunexposed skin cells but is virtually absent from sunprotected skin (Ponten et al., 1995; Ren et al., 1996). Likewise, p53 is observed rarely in normal squamous cells of the sun-protected human tongue (Shintani et al., 1995), in agreement with our observations on mouse tongue. When it is activated by stress, p53 characteristically functions to stall cell division. However, p53 in mouse tongue cannot be functioning to stall cell division, because p53 is restricted to intragemmal cells that do not divide (F arbman, 1980; Zhang et al., 1995). We conclude that, 
although most of the cited instances of p53 activation involve differentiating, dividing, exogenously stressed, or cancerous cells (however, see Atadja et al., 1995; van Looken Campagne and Gill, 1998), none of these applies to the mouse gustatory system in which, in neonates and adults, p53 is characteristically associated with nonmitotic, aged, dying taste receptor cells.

The p53 null mutation did not appear to alter Bax levels in the cerebrum (Miyashita et al., 1994) or Bax staining in taste cells. Although taste cell death rates may have been suppressed moderately in $\mathrm{p} 53^{-1-}$ mice in which taste buds contained $\approx 20 \%$ more cells/section, p53 clearly was not required for taste bud homeostasis or Bax expression. Consequently, other death signals must up-regulate bax in p53-deficient taste buds. One candidate death signal is p73 KET, a p53-like gene that is expressed selectively in the vallate gustatory epithelium and leads to apoptosis when transfected (J ost et al., 1997; Kaghad et al., 1997; Schmale and Bamberger, 1997).

\section{Implications of intragemmal cell death for gustatory sensory coding}

Why is it that the coding of taste qualities is not severely disrupted by the turnover of receptor cells that continually requires taste axons to make new connections? For example, how do sweet-best fibers make meaningful new contacts after the death of sweet-best receptor cells? One somewhat elaborate explanation proposes that, as taste receptor cells age, they alter their taste sensitivity and shift position. For example, the oldest cells may move to the core of the bud, where they become sucrose-best. If, as this model also assumes, one axon type (sucrose-best in this example) terminates preferentially in the core, then it would generate a reliable signal for sweetness, because its axonal contacts would always be limited to old, sucrosebest receptor cells (Beidler, 1961). However, older cells (BrdU/Bax positive) and dying cells (TUNE L-positive) were scattered from the margins to the core of the taste bud rather than being clustered in one place. Consequently, if a fiber class were confined to a particular part of the taste bud, then it would thwart rather than augment axonal contact with older taste cells. The long-term stability of taste quality signaling during receptor cell turnover is more likely to be optimized by the ample branching of axons throughout the taste bud, ther eby allowing access to all suitable receptor cells (Beidler, 1969; Oakley, 1975; Cheal et al., 1977).

\section{CONCLUSIONS}

In taste buds and other renewing epithelia, new cells continually replace aged cells that are killed by death cascades. In our initial investigation of programmed cell death, a version of TUNEL staining indicated that gustatory cells may die apoptotically as they turn over. p53 and Bax commonly were coexpressed in older gustatory cells and were associated with apoptotic morphol ogy. We hypothesize that, as part of normal taste cell replacement, postmitotic, aged taste cells can employ p53 and other factors to up-regulate the cell death promoter Bax, leading to DNA fragmentation and taste cell death. More generally, the presence of p53 in postmitotic taste cells means that stress-damaged DNA in cycling cells is not the only occasion for p53 expression. The dispersed location of dying cells throughout a taste bud rules against some spatial mechanisms that might stabilize taste signaling during cell turnover.

\section{ACKNOWLE DGME NT}

Wethank Anne Lawton for assistance.

\section{LITERATURE CITED}

Ansari B, Coates PJ , Greenstein BD, Hall PA. 1993. In situ end-labeling detects DNA strand breaks in apoptosis and other physiological and pathological states. J Pathol 170:1-8.

Atadja P, Wong H, Garkavtsev I, Veillette C, Riabowol K. 1995. Increased activity of p53 in senescing fibroblasts. Proc Natl Acad Sci USA 92:8348-8352.

Beidler LM. 1961. Taste receptor stimulation. Progr Biophys Biophysical Chem 12:107-151.

Beidler LM. 1969. Innervation of rat fungiform papilla. In: Pfaffmann C, editor. Olfaction and taste III. N ew York: Rockefeller University Press. p 352-369.

Beidler LM, Smallman RL. 1965. Renewal of cells within taste buds. J Cell Biol 27:263-272.

Bergeron L, Yuan J. 1998. Sealing one's fate: control of cell death in neurons. Curr Opinion Neurobiol 8:55-63.

Boise LH, Gonzalez GM, Postern CE, Ding L, Lindsten T, Turka LA, MaoX, Nuñez G, Thompson CB. 1993. Bcl-x, a bcl-2-related genethat functions as a dominant regulator of apoptotic cell death. Cell 74:597-608.

Cheal ML, Dickey WP, J ones LB, Oakley B. 1977. Taste fiber responses during reinnervation of fungiform papillae. J Comp Neurol 172:627646.

Chittenden T, Harrington EA, O'Connor R, Flemington C, Lutz RJ , Evan GI, Guild BC. 1995. Induction of apoptosis by the bcl-2 homolog bak. Nature 374:733-736.

Coates PJ . 1994. Molecular methods for the identification of apoptosis in tissues. J Histotech 17:3-9.

Cooper D, Oakley B. 1998. Functional redundancy and gustatory development in bdnf null mutant mice. Dev Brain Res 105:79-84.

Cummings MC, Winterford CM, Walker NI. 1997. Apoptosis. Am J Surg Pathol 21:88-101.

Deckwerth TL, Easton RM, Knudson CM, Korsmeyer SJ , J ohnson EM. 1998. Placement of the Bcl 2 family member BAX in the death pathway of sympathetic neurons activated by trophic factor deprivation. Exp Neurol 152:150-162.

Deckwerth TL, Elliott LL, Knudson CM, J ohnson EM, Snider WD, Korsmeyer SJ . 1996. Bax is required for neuronal death after trophic factor deprivation and during development. Neuron 17:401-411.

Dekker NP, Lozada-Nur F, Lagenaur LA, MacPhail LA, Bloom CY, Regezi J A. 1997. Apoptosis-associated markers in oral lichen planus. J Oral Pathol Med 26:170-175.

Donehower LA, Harvey M, Slagle BL, McArthur MJ , Montgomery CA J r., Butel J S, Bradley A. 1992. Mice deficient for p53 are developmentally normal but susceptible to spontaneous tumours. Nature 356:215-221.

Easton RM, Deckwerth TL, Parsadanian AS, J ohnson EM J r. 1997. Analysis of the mechanism of loss of trophic factor dependence associated with neuronal maturation: a phenotype indistinguishable from Bax deletion. J Neurosci 17:9656-9666.

EI-Deiry WS, Tokino T, Velculescu VE, Levy DB, Parsons R, Trent J M, Lin D, Mercer E, Kinzler KW, Vogelstein B. 1993. WAF 1, a potential mediator of p53 tumor suppression. Cell 75:817-825.

Ellis RE, Yuan J Y, Horvitz HR. 1991. Mechanisms and functions of cell death. Annu Rev Cell Biol 7:663-698.

Farbman Al. 1980. Renewal of taste bud cells in rat circumvallate papillae. Cell Tissue Kinet 13:349-357.

Farmer G, Bargonetti J, Zhu H, Friedman P, Prywes R, Prives C. 1992. Wild-type p53 activates transcription in vitro. Nature 358:83-86. 
Farrow SN, White J H, Martinou I, Raven T, Pun KT, Grinham CJ , Martinou J C, Brown R. 1995. Cloning of a bcl-2 homologue by interaction with adenovirus E1B 19K. Nature 374:731-733.

Gavrieli Y, Aherman Y, Ben-Sasson SA. 1992. I dentification of programmed cell death in situ via specific labeling of nuclear DNA fragmentation. J Cell Biol 119:493-501.

Gorczyca W, Gong J, Darzynkiewicz Z. 1993. Detection of DNA strand breaks in individual apoptotic cells by the in situ terminal deoxynucleotide transferase and nick translation assays. Cancer Res 53:1945-1951.

Green DR, Reed J C. 1998. Mitochondria and apoptosis. Science 281:13091312.

Haake AR, Polakowska RR. 1993. Cell death by apoptosis in epidermal biology. J I nvest Dermatol 161:107-112.

Hansen R, Oren M. 1991. p53: from inductive signal to cellular effect. Curr Opin Genet Dev 7:46-51.

Harper JW, Adami GR, Wei N, Keyomarsi K, Elledge SJ. 1993. p21 cdk-interacting protein cipl is a potent inhibitor of $\mathrm{Gl}$ cyclin-dependent kinases. Cell 75:805-816.

Hollstein M, Sidransky D, Vogelstein B, Harris C. 1991. p53 mutations in human cancers. Science 253:49-53.

Hosley MA, Oakley B. 1987. Postnatal development of the vallate papilla and taste buds in rats. Anat $\operatorname{Rec} 218: 216-222$.

Huang CC, Chen K, Huang TY. 1995. Immunohistochemical studies of sensory neurons in rat olfactory epithelium. Eur Arch Otorhinolarynol 252:86-91.

Hughes PE, Alexi T, Schreiber SS. 1997. A role for the tumour suppressor gene p53 in regulating neuronal apoptosis. Neuroreport 8:5-12.

J acobson MD, Burne J F, Raff MC. 1994. Programmed cell death and Bcl-2 protection in the absence of a nucleus EMBOJ 13:1899-1910.

J acobson MD, Weil M, Raff MC. 1997. Programmed cell death in animal devel opment. Cell 88:347-354

J ordan RC, Catzavelos GC, Barrett AW, Speight PM. 1996. Differentia expression of bcl-2 and bax in squamous cell carcinomas of the oral cavity. Eur J Cancer, Oral Oncol 32B:394-400.

J ost CA, Marin MC, Kaelin WG J r. 1997. p73 is a human p53-related protein that can induce apoptosis. Nature 389:122-123.

Kaghad M, Bonnet $\mathrm{H}$, Yang A, Creancier L, Biscan J -C, Valent A, Minty A, Chalon P, Lelias J -M, Bumont X, Ferrara P, McKeon F, Caput D. 1997. Monallelically expressed gene related to $\mathrm{p} 53$ at $1 \mathrm{p} 36$, a region fre quently deleted in neuroblastoma and other human cancers. Cell 90:809-819.

Kastan MB, Onyekwere O, Sidransky D, Vogelstein B, Craig RW. 1991. Participation of p53 in the cellular response to DNA damage. Cancer Res 51:6304-6311.

Kerr JFR, Wyllie AH, Currie AR. 1972. Apoptosis: a basic biological phenomenon with wide-ranging implication in tissue kinetics. $\mathrm{Br}$ J Cancer 26:239-257.

Kiefer MC, Braucer MJ , Powers VC, Wu J J , U mansky SR, Tomei LD, Barr PJ . 1995. Modulation of apoptosis by the widely distributed $\mathrm{BCl}-2$ homologue Bak. Nature 374:736-739.

Kinnamon J C, Sherman TA, Roper SD. 1988. Ultrastructure of mouse vallate taste buds: III. Patterns of synaptic connectivity. J Comp Neurol 270:1-10.

Knapp L, Lawton A, Oakley B, Wong L, Zhang C. 1995. Keratins as markers of differentiated taste cells. Differentiation 58:341-349.

Krajewski S, Krajewska M, Shabaik A, Miyashita T, Wang HG, Reed J C. 1994. Immunohistochemical determination of in vivo distribution of Bax, a dominant inhibitor of Bcl-2. AmJ Pathol 45:1323-1336.

Krajewski S, Mai J K, Krajewska M, Sikorska M, Mossakowski MJ, Reed JC. 1995. Upregulation of Bax protein levels in neurons following cerebral ischemia. J Neurosci 15:6364-6376.

Kuerbitz SJ , Plunkett BS, Walsh WV, Kastan MB. 1992. Wild-type p53 is a cell cycle checkpoint determinant following irradiation. Proc $\mathrm{N}$ atl Acad Sci USA 89:7491-7495.

Levine AJ . 1997. p53, the cellular gatekeeper for growth and division. Cell 88:323-331.

Maruoka $Y$, Harada $H$, Mitsuyasu $T$, Seta $Y$, Kurokawa $H$, J ajiyama M, Toyoshima K. 1997. Keratinocytes becometerminally differentiated in a process involving programmed cell death. Biochem Biophys Res Comm 238:886-890.

McCall CA, Cohen J J . 1991. Programmed cell death in terminally differentiating keratinocytes: role of endogenous endonuclease. J Invest Dermatol 97:111-114.
Messam CA, Pittman RN. 1998. Asynchrony and commitment to die during apoptosis. Exp Cell Res 238:389-398.

Mills J C, Lee VM-Y, Pittman RN. 1998. Activation of a PP2A-like phosphatase and dephosphorylation of $\tau$ protein characterize onset of the execution phase of apoptosis J Cell Sci 111:625-636.

Miyashita T, Krajewski S, Krajewska M, Wang HG, Lin HK, Lieberann DA H offman B, Reed J C. 1994. Tumor suppressor p53 is a regulator of bcl-2 and bax gene expression in vitro and in vivo. Oncogene 9:1799-1805.

Miyashita T, Reed J C. 1995. Tumor suppressor p53 is a direct transcriptional activator of human bax gene. Cell 80:293-299.

Oakley B. 1975. Receptive fields of cat taste fibers. Chem Senses Flavor 2:52-63.

Oakley B, LaBelle DE, Riley RA, Wilson K, Li LW. 1991. The rate and locus of development of rat vallate taste buds. Dev Brain Res 58:215-221.

Oltvai Z, Milliman C, Korsmeyer SJ . 1993. BCl-2 heterodimerizes in vivo with a conserved homol og, bax, that accel erates programmed cell death. Cell 74:609-619.

Polakowska RR, Piacentini M, Bartlett R, Goldsmith LA, HaakeAR. 1994 Apoptosis in human skin development: morphogenesis, periderm, and stem cells. Dev Dyn 199:176-188

Ponten F, Berne B, Ren ZP, Nister M, Ponten J . 1995. Ultraviolet light induces expression of p53 and p21 in human skin: effect of sunscreeen and constitutive p21 expression in skin appendages. J I nvest Dermatol 105:402-406.

Potten CS, Wilson JW, Booth C. 1997. Regulation and significance of apoptosis in the stem cells of the gastrointestinal epithelium. Stem Cells 15:82-93.

Ren Z-P, Pontén F, Nistér M, Pontén J . 1996. Two distinct p53 immunohistochemical patterns in human squamous-cell skin cancer, precursors and normal epidermis. Int J Cancer 69:174-179.

Sabbatini P, Lin J, Levine AJ, White E. 1995. Essential role for p53mediated transcription in E 1A-induced apoptosis. Genes Dev 9:21842192.

Sakamuro D, Eviner V, Elliott KJ, Showe L, White E, Prendergast, GC. 1995. C-myc induces apoptosis in epithelial cells by both p53-dependent and p53-independent mechanisms. Oncogene 11:2411-2418.

Schmale H, Bamberger C. 1997. A novel protein with a strong homology to the tumor suppressor, p53. Oncogene 15:1363-1367.

Schmid P, Lorenz A, Hameister H, Montenarh M. 1991. Expression of p53 during mouse embryogenesis. Development 113:857-865.

Selvakumaran M, Lin HK, Miyashita T, Wang HG, Krajewski S, Reed J C, H offman B, Liebermann D. 1994. I mmediate early up-regulation of bax expression by p53 but not TGF- $\beta 1$ : a paradigm for distinct apoptotic pathways. Oncogene 9:1791-1798.

Shintani S, Yoshihama Y, Emilio AR, Matsumura T. 1995. Overexpression of p53 is an early event in the tumorigenesis of oral squamous cell carcinomas. Anticancer Res 15:305-308.

Spandau DF. 1994. Distinct conformations of p53 are observed at different stages of keratinocyte differentiation. Oncogene 9:1861-1868.

Susin SA, Lorenzo J K, Zamzami N, Marzo I, Snow BE, Brothers GM, Maggion J , J acotot E, Costatini P, Loeffler M, Larochette N, Goodlett DR, Aebersold R, Siderovski DP, Penninger J M, Kroemer G. 1999. Molecular characterization of mitochondiral apoptosis-inducing factor. Nature 397:441-446.

Takeda M. 1979. Tritiated thymidine autoradiographic study of taste buds in the mouse. Acta Anat Nippon 54:230-231.

Takeda M, Suzuki Y, Obara N, Nagai Y. 1996. A poptosis in mousetaste buds after denervation. Cell Tissue Res 286:55-62.

Tamada Y, Takama H, Kitamura T, Yokochi K, Nitta Y, I keya T, Matsumoto Y. 1994. I dentification of programmed cell death in normal human skin tissues by using specific labeling of fragmented $\mathrm{DNA}$. $\mathrm{Br}$ 」 Dermatol 131:521-524.

Ucker DS. 1991. Death by suicide: one way to go in mammalian cellular development? New Biol 3:103-109.

van Lookeren Campagne M, Gill R. 1998. Tumor-suppressor p53 is expressed in proliferating and newly formed neurons of the embryonic and postnatal rat brain: comparison with expression of the cell cycle regulators p21 Waf1/Cip1, p27kip1, p57Kip2, p16!nk-4a, cyclin G1, and the proto-oncogene Bax. J Comp Neurol 397:181-198.

Vekrellis K, McCarthy MJ , Watson A, Whitfield J , Rubin LL, Ham J . 1997. Bax promotes neuronal cell death and is downregulated during the development of the nervous system. Devel opment 124:1239-1249. 
White FA, Keller-Peck CR, Knudson CM, Korsmeyer SJ , Snider WD. 1998. Widespread elimination of naturally occurring neuronal death in Bax-deficient mice. J Neurosci 18:1428-1439.

Wiman K. 1997. p53: Emergency brake and target for cancer therapy. Exp Cell Res 237:14-18.

Wyllie AH, Kerr J FR, Currie AR. 1980. Cell death: the significance of apoptosis. Int Rev Cytol 68:251-306.

Yin C, Knudson CM, Korsmeyer SJ , Van Dyke T. 1997. Bax suppresses tumorigenesis and stimulates apoptosis in vivo. Nature 385:637-640.

Yin Y, Tainsky MA, Bischoff FZ, Strong LC, Wahl GM. 1992. Wild-type p53 restores cell cycle control and inhibits gene amplification in cells with mutant p53 alleles. Cell 70:937-948.
Yonish-Rouach E, Deguin V, Zaitchouk T, Breugnot C, Mishal Z, J enkins J, May E. 1995. Transcriptional activation plays a role in the induction of apoptosis by transiently transfected wild-type p53. Oncogene 11:2197-2205.

Zhang C, Cotter M, Lawton A, Oakley B, Wong L, Zeng Q. 1995. Keratin 18 is associated with a subset of older taste cells in the rat. Differentiation 59:155-162.

Zhang C, Oakley B. 1996. The distribution and origin of keratin 20containing taste buds in rat and human. Differentiation 61:121-127.

Zhang C, Brandemihl A, Lau D, Lawton A, Oakley B. 1997. BDNF is required for the normal development of taste neurons in vivo. Neurore port 8:1013-1017. 